\title{
Effects of Plaster Thicknesses on Cyclic Behavior of Infill Walls with Different Materials
}

\author{
Mehmet Emin Arslan ${ }^{1}$, Elif Agcakoca ${ }^{2 *}$, Merve Şentürk² \\ ${ }^{1}$ Civil Engineering Department, Faculty of Technology, Duzce University, 81620 Düzce, Turkey \\ 2 Civil Engineering Department, Faculty of Engineering, Sakarya University, 54050 Sakarya, Turkey \\ * Corresponding author, e-mail: elifd@sakarya.edu.tr
}

Received: 10 January 2020, Accepted: 15 April 2020, Published online: 12 May 2020

\begin{abstract}
Reinforced concrete structure systems are usually designed as frame or shear wall-frame systems. It is possible to reduce the deformation and displacement in the system by increasing the structural stiffness. Besides, large displacements on the floors caused by horizontal load are damped by the cracks in these walls. The present paper aims to examine the effects of materials used in the wall construction as well as thickness of the plaster on the behavior of infill walls under cyclic loads. In order to investigate the above mentioned effects, three Infill walls that were produced from three different materials namely, horizontal hollow bricks, pumice blocks and aerated concrete blocks were tested in three setups (without plaster, with $1 \mathrm{~cm}$ plaster and $2.5 \mathrm{~cm}$ plaster on it). In order to determine pure wall contribution, the infill walls were placed in a steel frame test set-up which was hinged from all four corners and were then exposed to cyclic loads taking into account the displacement controlled loading protocol proposed in FEMA 461. Right after applying the plaster to the infill walls, load carrying and energy dissipation capacities of the walls were examined comparatively. Loaddisplacement, backbone curve and cumulative dissipated energy curves of each infill walls are generated using the data collected from the experiments and the infill walls behaviors are graphically explained. Test results showed that existence and thickness of plaster significantly affected cyclic behavior of the test walls by increasing energy dissipation capacities and load carrying capacities.
\end{abstract}

Keywords

infill walls, plaster thicknesses, cyclic loading, bricks, pumice blocks, aerated concrete blocks, load carrying, energy dissipations

\section{Introduction}

Structures are expected to have all essential structural design criteria (certain degree of safety, sufficient level of strength, stability and rigidity) during their lifetime. However, structures fail to show the expected behavior as some of the elements or installations are not considered to have a tangible effect and thus are neglected during the design and construction phase $[1,2]$.

Accurate calculation of structural behavior under the loads that a building will encounter during its life is not only provided by knowing the behavior of primary structural elements like columns, beams and shear walls, but also by understanding the behavior of the secondary elements like infill walls. Therefore, getting to understand the dynamic behavior of infill walls under loading provides us with more accurate information about the structure's behavior. During the preliminary stages of building design, it is assumed that, although infill walls contribute to stiffness and strength of the building they are still not taken into consideration in the analysis as an important factor but are just accepted as a load. Conversely, infill walls are not dead loads only, rather they are earthquake resistance members subjected to the lateral earthquake loads like structural members [3].

Regarding the effect of infill walls on increasing rigidity, dimensions and mechanical properties as well as relative stiffness of the frame to which the infill wall is attached, they seem to play an important role [4]. According to Smith [4] infill walls within the building are included in the calculations, under the loads acting on the floor levels using the equivalent pressure rod principle. In this approach, it is assumed that infill walls behave like a pressure bar between the point where the force is applied and the corner point of the wall. In addition, the effect of the infill walls on the design parameters under seismic loading has been studied numerically [5]. Besides the contribution the partition walls have to the building, there are 
some negative aspects of partition walls such as, soft layer, torsion, and short column effect, which need to be considered as well. During such adverse events, the structure can apply much more damage than expected while under the effect of seismic load $[6,7]$. This is due to the fact that infill walls behave like a shear wall until they are fractured, similar to the torsional effect created by the shear walls, which are not placed symmetrically on the floor plan. In addition, infill walls which are under the effect of horizontal loading in the reinforced concrete frame system do not have the same horizontal stiffness as the frame which makes them more vulnerable and are damaged more than the frame [8]. Furthermore, because of poor workmanship during the construction phase, not covering the column longitudinal rebar properly may cause local breakage of infill walls placed in the frame system. Therefore, infill walls that are not taken into account or not properly placed in the project will not reflect actual structural behavior [9-11].

Earthquakes cause large displacement between the floors in the structures and this displacement is slightly damped by cracks in the walls. Infill walls in the reinforced concrete frame system contribute to the rigidity of the system and act as an additional load to the structure mass. But, as the stiffness and the loads are compared, it is seen that infill walls have more benefit to the stiffness of the structure $[12,13]$. Besides, as infill walls change the dynamic behavior of the building system by changing the mode of collapse in the mechanism state. In order to carry out the damage estimation forecast for structures under loads precisely, conducting experimental studies where cyclic quasi static force is applied is necessary $[1,2,14,15]$. The most effective parameters regarding the behavior of infill walls under cyclic loading are the axial load and aspect ratio [4]. In several studies, the shake table is also used for determining the behavior of infill walls under the effect of seismic force [16, 17]. Various strengthening techniques are used in infill walls under the effect of seismic loading to make the structural behavior efficient. These techniques include, reinforcing by using fiber materials [18-24], steel strip [25] and epoxy injection.

Recent earthquakes have shown the importance of cyclic behavior for both existing and newly designed buildings [26-28], and bridge [29]. The behavior of infill walls depends on the wall blocks used as well as the properties of the binder material. Infill walls show different behavior depending on the thickness of the plaster applied on it as well as the used materials (brick, aerated concrete, and pumice blocks). The plaster is applied to the infill walls to protect against the natural conditions as well as to ensure that the elements forming the infill walls work together. In addition, it increases the wall resistance against horizontal and vertical forces and provides stiffness to the wall. For these reasons, it is necessary to pay utmost attention to plaster applications and check its compliance with the standards. This experimental study aims to determine the effects of the materials used in the wall construction along with the thickness of plaster applied to the wall on dynamic behavior of the infill walls under cyclic loading. Also, the energy dissipation capacity, stiffness, horizontal load carrying capacities of the infill walls under cyclic loads using different materials and different thicknesses of plaster applied were determined and compared with each other using the achieved results.

\section{Materials and methods}

In this section, experimental studies are conducted to investigate the behavior of infill walls with different plaster thicknesses under horizontal cyclic loading. The details of the materials used in the construction of the walls, construction stages of the walls, test setup, loading system and details of the measurement device are explained as follows.

\subsection{Properties of materials used in the tests and test walls} In order to investigate the infill walls behavior under cyclic loading, 9 infill wall samples with $150 \mathrm{~cm} \times 150 \mathrm{~cm}$ dimensions were produced. Some properties of brick and pumice blocks and aerated concrete blocks used in the producing of infill walls are given in Table 1. Mixing ratios and the average compressive strength of masonry and plaster mortar used in wall construction are presented in Table 2.

Table 1 Properties of materials used in infill wall construction

\begin{tabular}{lccc}
\hline Materials & Brick Block & Bims Block & $\begin{array}{c}\text { Aerated } \\
\text { concrete }\end{array}$ \\
\hline Size & $19 \times 13.5 \times 19 \mathrm{~cm}$ & $39 \times 18.5 \times 19 \mathrm{~cm}$ & $60 \times 19 \times 25 \mathrm{~cm}$ \\
Unit weight & $650 \mathrm{~kg} / \mathrm{m}^{3}$ & $700 \mathrm{~kg} / \mathrm{m}^{3}$ & $400 \mathrm{~kg} / \mathrm{m}^{3}$ \\
$\begin{array}{l}\text { Compressive } \\
\text { Strength }\end{array}$ & $2 \mathrm{MPa}$ & $2.1 \mathrm{MPa}$ & $2.5 \mathrm{MPa}$ \\
\hline
\end{tabular}

Table 2 Properties of masonry used in the wall constructions

\begin{tabular}{lccc}
\hline \multirow{2}{*}{$\begin{array}{l}\text { Masonry } \\
\text { and }\end{array}$} & Material & Volume & $\begin{array}{c}\text { Average Compressive } \\
\text { Strength (MPa) }\end{array}$ \\
\cline { 2 - 4 } $\begin{array}{l}\text { Mortar } \\
\text { Mlaster }\end{array}$ & Sand & 3 & 2.56 \\
\hline
\end{tabular}




\subsection{Test setup and loading protocol}

In order to determine experimental cyclic behavior of infill walls, an experimental arrangement which is hinged from four corners was used. Cyclic loads were applied to the test elements by servo controlled actuator system with $500 \mathrm{kN}$ loading and $500 \mathrm{~mm}$ displacement capacity. The cyclic loads applied to the test elements were measured with a loadcell. The peak displacements corresponding to the cyclic loads were determined using linear potentiometric displacement transducers (LPDT). These applied loads and their corresponding displacements were recorded simultaneously by the help of data acquisition system in $0.125 \mathrm{sec}$ intervals. Fig. 1 shows a schematic view of the loading and measuring system [30].

During the experiments, the loading protocol proposed in FEMA 461 given in Fig. 2 was used on infill walls [22]. According to the protocol specified in FEMA 461, the displacement values applied to the test elements consisted of gradually increasing and repeated load cycles. FEMA 461 states that the cyclic load applied to the experimental elements should be repeated at least twice. It is also stated that during the cyclic loading application to the Infill wall, maximum displacement determined in at least 10 cycles should be reached.

Cyclic loads applied to the infill wall samples on the wall test setup and the displacements resulting from these loads are measured simultaneously at $0.125 \mathrm{sec}$ intervals with the help of the data collection unit and recorded to the computer. Also, during the cyclical loadings, the displacements of test samples of the infill walls are determined as the displacement ratio. The displacement ratio is obtained by dividing the top point displacement of the infill wall element by the infill wall length. The cyclical loads are carried out by displacement control method.

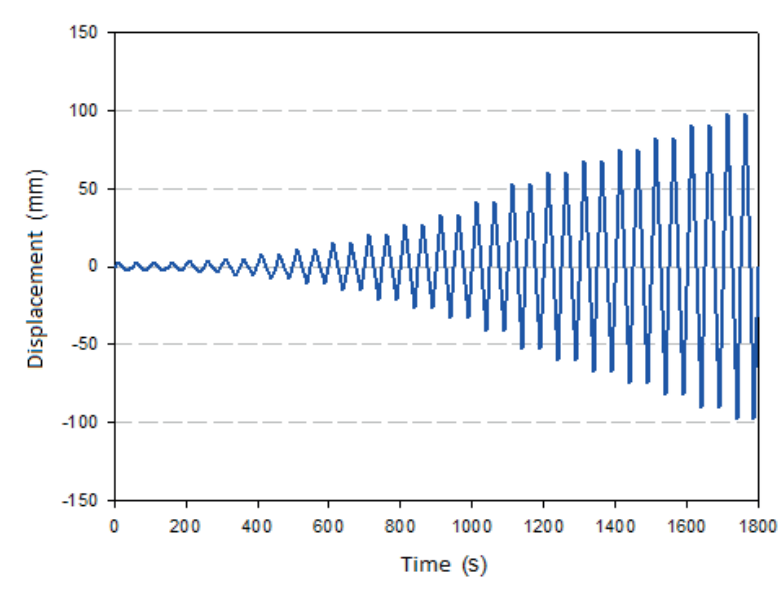

Fig. 2 Loading protocol used during tests

\subsection{Experimental procedure}

Within the scope of the experiments, three pieces of each materials, including horizontal hollow brick, pumice blocks and aerated concrete blocks with different plaster thicknesses, were used for producing total 9 infill walls with $150 \mathrm{~cm} \times 150 \mathrm{~cm}$ dimensions. One of each infill walls were produced as non-plastered. For the remaining two samples of each type, $1 \mathrm{~cm}$ and $2.5 \mathrm{~cm}$ of plasters were applied. After the application of plasters at predetermined thickness, the plaster was allowed to be dried for 28 days, in order to fully adhere to the infill walls and to gain strength. In order to prevent crack formation, plaster was water cured regularly. As soon as the plasters dried up completely, they were ready for testing.

The infill walls prepared to be subjected to cyclic loading experiments were placed in the articulated test setup from the four corners as shown in Fig. 3 in order to determine the pure wall additive so that the non-plasters were referenced. Specific attention was paid to ensure that there is no gap between the wall and the experimental apparatus in order

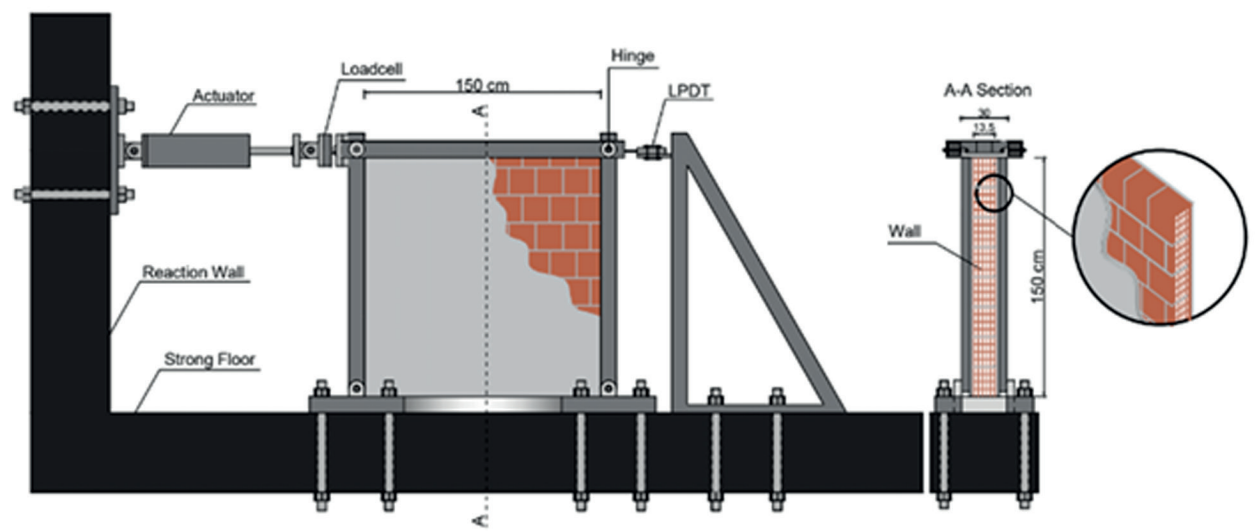

Fig. 1 Test setup 


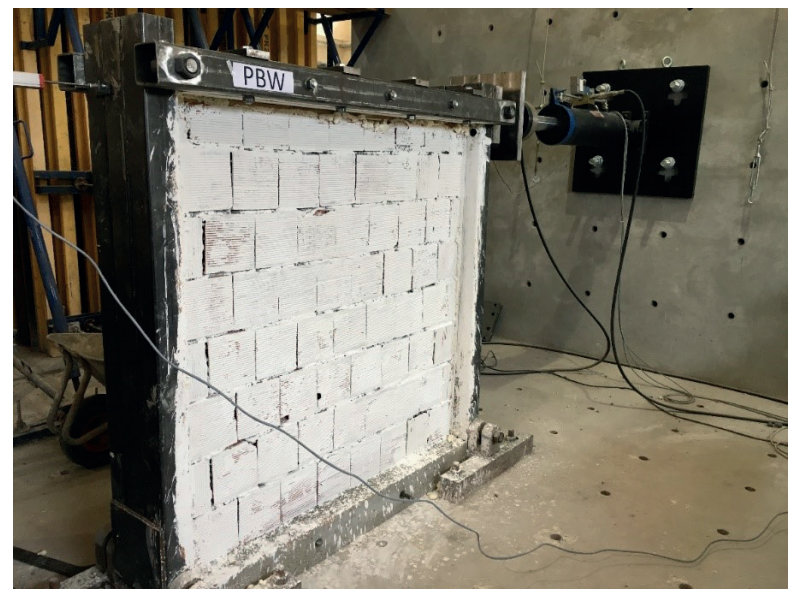

Fig. 3 A scene from cyclic test of infill wall

to distribute the cyclic load applied to the entire surface of the wall element during the placement of the walls in the experimental arrangement. The properties of the samples and the names of the samples subjected to the test are given in Table 3. In this experimental study different plaster thicknesses applied to the infill walls. The effect of plaster thickness on the behavior of infill walls were examined under cyclical loading. The samples are placed in the test device carefully to ensure that cyclical loading distributed evenly over the entire surface of the infill wall element.

\section{Test results}

The hysterical load-displacement curves of the infill walls produced using brick, pumice and aerated concrete blocks are examined under lateral cyclic loads are given in Fig. 4, respectively.

When the hysterical load-displacement curve of the PBW is examined, the maximum load obtained load in pushing direction is $43.35 \mathrm{kN}$ and the displacement corresponding

\begin{tabular}{|c|c|}
\hline PBW & Non-plastered infill wall made of horizontal hollow bricks \\
\hline BW-1.0 & $\begin{array}{c}1 \mathrm{~cm} \text { plaster applied infill wall made of horizontal hollow } \\
\text { bricks }\end{array}$ \\
\hline BW-2.5 & $\begin{array}{l}2.5 \mathrm{~cm} \text { plaster applied infill wall made of horizontal } \\
\text { hollow bricks }\end{array}$ \\
\hline PPW & Non-plastered infill wall made of pumice blocks \\
\hline PW-1.0 & $1 \mathrm{~cm}$ plaster applied infill wall made of pumice blocks \\
\hline PW-2.5 & $2.5 \mathrm{~cm}$ plaster applied infill wall made of pumice blocks \\
\hline PAW & Non-plastered infill wall made of aerated concrete blocks \\
\hline AW-1.0 & $\begin{array}{l}1 \mathrm{~cm} \text { plaster applied infill wall made of aerated concrete } \\
\text { blocks }\end{array}$ \\
\hline AW-2.5 & $\begin{array}{l}2.5 \mathrm{~cm} \text { plaster applied infill wall made of aerated concrete } \\
\text { blocks }\end{array}$ \\
\hline
\end{tabular}

to this value is $20.97 \mathrm{~mm}$. For pulling direction these values are $39.40 \mathrm{kN}$ and $20.96 \mathrm{~mm}$. When the curve of the BW-1.0 wall is examined, the maximum load obtained in pushing and pulling direction and corresponding displacement values $84.34 \mathrm{kN}-40.14 \mathrm{~mm}$ and $73.03 \mathrm{kN}-28.06 \mathrm{~mm}$, respectively. The same values are $107.48 \mathrm{kN}-32.88 \mathrm{~mm}$ and $105.88 \mathrm{kN}-32.86 \mathrm{~mm}$ for BW-2.5 infill wall.

When the load-displacement curves of the filler walls produced with pumice blocks are examined, the maximum loads and corresponding displacements obtained in pushing and pulling direction for PPW infill wall are $64.17 \mathrm{kN}-26.15$ $\mathrm{mm} 71.77 \mathrm{kN}-26.14 \mathrm{~mm}$, respectively. The same values are $128.19 \mathrm{kN}-39.39 \mathrm{~mm}$ and $124.91 \mathrm{kN}-41.24 \mathrm{~mm}$ PW-1.0 infill wall and $129.59 \mathrm{kN}-41.02 \mathrm{~mm}$ and $144.89 \mathrm{kN}-59.63$ $\mathrm{mm}$ for PW-2.5 infill wall with the same order.

When the hysterical Load-Displacement Curve of the walls produced using aerated concrete blocks are examined, the obtained maximum load and corresponding displacements for pushing and pulling directions are $63.59 \mathrm{kN}-52.39 \mathrm{~mm}$ and $46.09 \mathrm{kN}-52.39 \mathrm{~mm}$ for PAW, $99.71 \mathrm{kN}-41.19 \mathrm{~mm}$ and $71.99 \mathrm{kN}-39.94 \mathrm{~mm}$ for AW-1.0 and finally, $100.41 \mathrm{kN}-41.16 \mathrm{~mm}$ and $109.08 \mathrm{kN}-41.15 \mathrm{~mm}$ for AW-2.5 infill wall, respectively. When the load-displacement curves of infill walls are examined, the cyclic behaviors are approximately symmetrical.

\section{Discussion}

\subsection{Load carrying capacities}

The backbone curves of infill walls obtained from hysterical cyclic loading by taking peak load and corresponding values are illustrated in Fig. 5. The effect of plaster thickness on load carrying capacity of infill walls can be clearly seen in the figures.

In addition, load capacity and stiffness values of 9 test samples are given in Table 4 for different cycle numbers. When the graphs were examined, the maximum load was obtained for PW-2.5 and this was followed by PW-1.0. This result can be explained porous structure of the pumice blocks that porosity increases the bond between wall and plaster. The lowest load carrying capacity was reached for PBW, which is the most widely, used material in infill wall construction. As seen from Fig. 5, the resistance of the infill wall is directly proportional to the thickness of the plaster applied to them. Based on these results, it can be said that the application of plaster has a significant effect on the behavior of the infill walls on structural behavior of the building. 


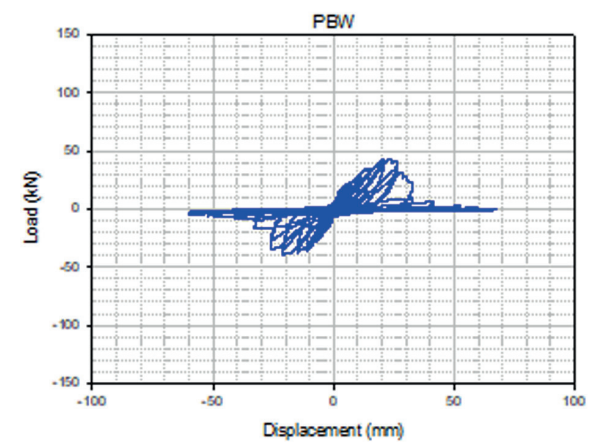

(a)

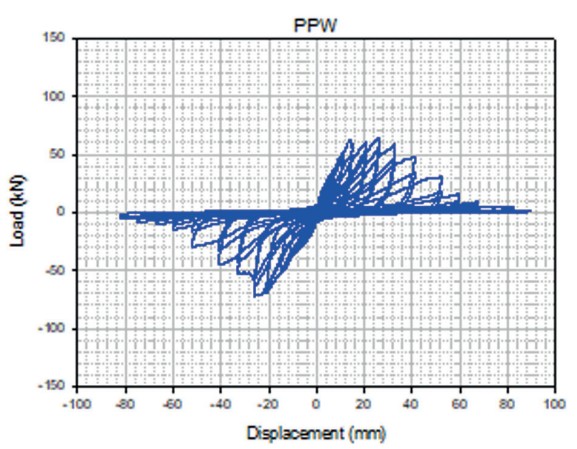

(d)

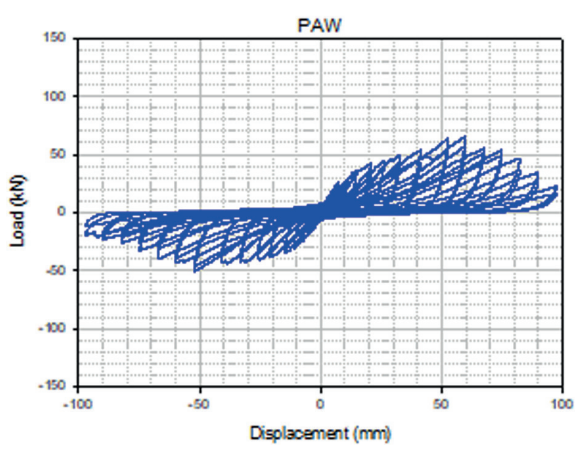

(g)

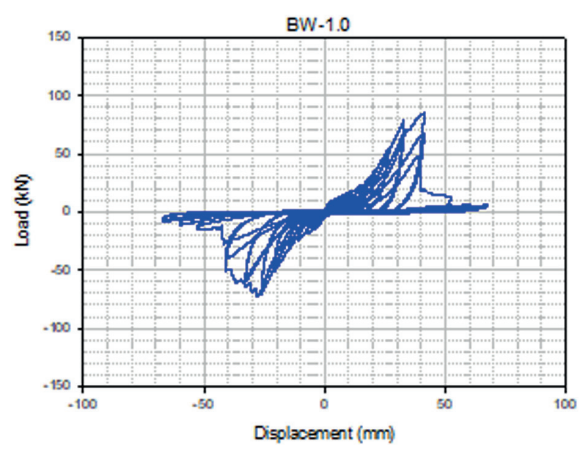

(b)

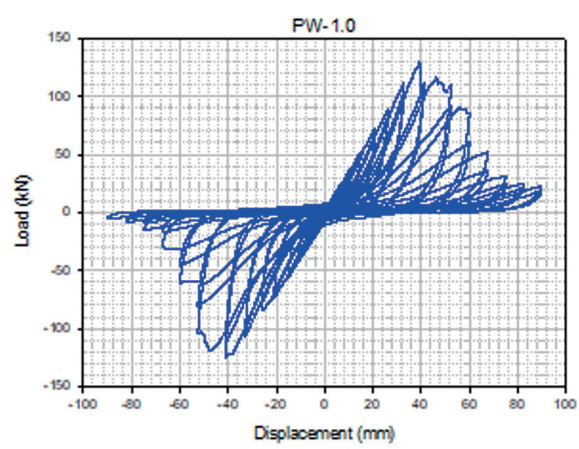

(e)

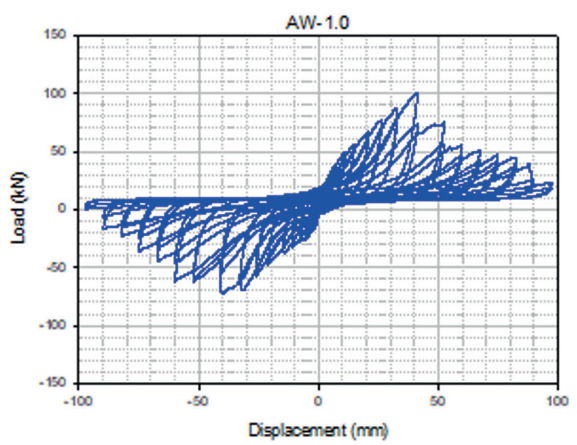

(h)

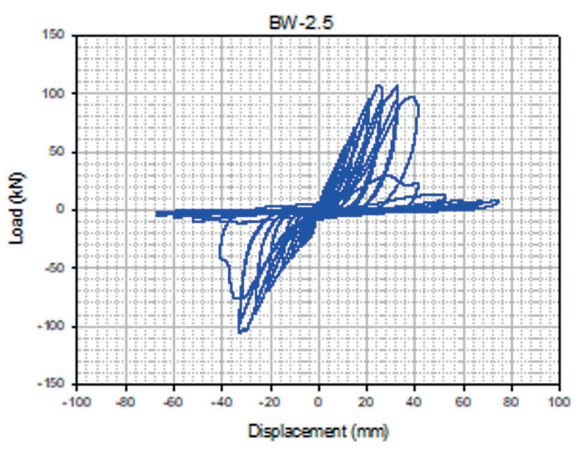

(c)

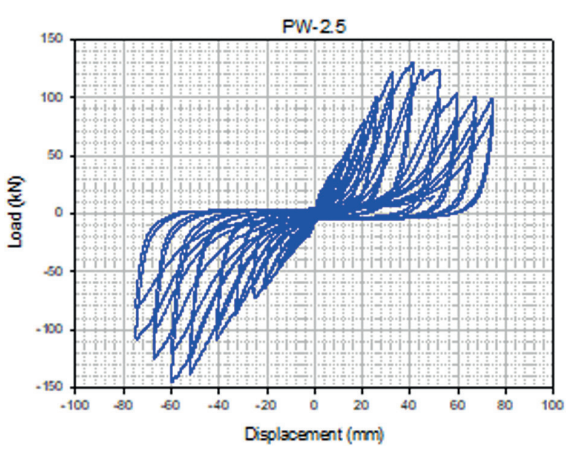

(f)

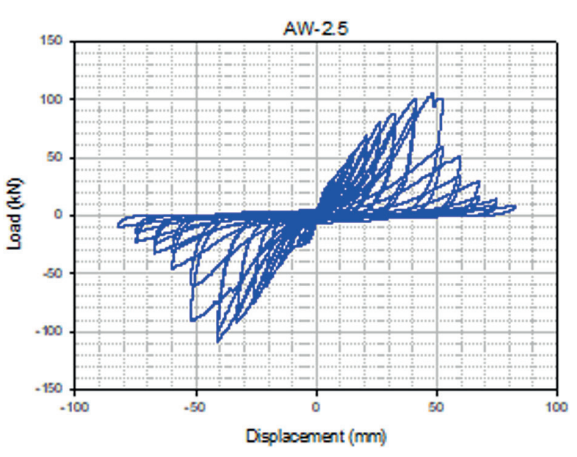

(i)

Fig. 4 Hysterical load-displacement curve of infill walls, (a) PBW hysterical load-displacement; (b) BW-1.0 hysterical load-displacement; (c) BW-2.5 hysterical load-displacement; (d) PPW hysterical load-displacement; (e) PW-1.0 hysterical load-displacement; (f) PW-2.5 hysterical load-displacement; (g) PAW hysterical load-displacement; (h) AW-1.0 hysterical load-displacement; (1) AW-2.5 hysterical load-displacement

A bar diagram was obtained using the load carrying capacities of Infill walls for better understanding and differentiating the values for each wall is illustrated in Fig. 6.

Under push force of the cyclic loading, the application of $1 \mathrm{~cm}$ plaster to all the tested infill walls increased the load carrying capacity by $95 \%$ in PBW, $92 \%$ in PPW and $55 \%$ in PAW walls. Under pull force of the cyclic loading, the application of $1 \mathrm{~cm}$ plaster to all the tested infill walls increased the load carrying capacity by $85.2 \%$ in PBW, $74 \%$ in PPW and $55 \%$ in PAW walls. It means that by increasing the plaster thickness, load carrying capacities of the infill walls increased in all three types.
Under pull force of the cyclic loading, the application of $2.5 \mathrm{~cm}$ plaster to all the tested infill walls increased the load carrying capacity by $148 \%$ in PBW, $101 \%$ in PPW and $58 \%$ in PAW walls. Under pull force of the cyclic loading, the application of $2.5 \mathrm{~cm}$ plaster to all the tested infill walls, increased the load carrying capacity by $169 \%$ in PBW, $157 \%$ in PPW and $136 \%$ in PAW walls. It can be inferred that by increasing the plaster thickness, load carrying capacities of the infill walls increased in all three types.

Under push force of the cyclic loading, the application of $1 \mathrm{~cm}$ plaster to all the tested infill walls increased, the stiffness by $10.5 \%$ in PBW, $32 \%$ in PPW and $100 \%$ in 


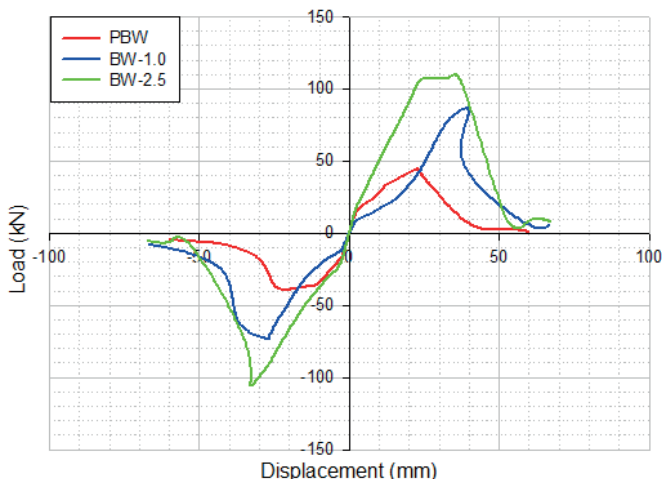

(a)

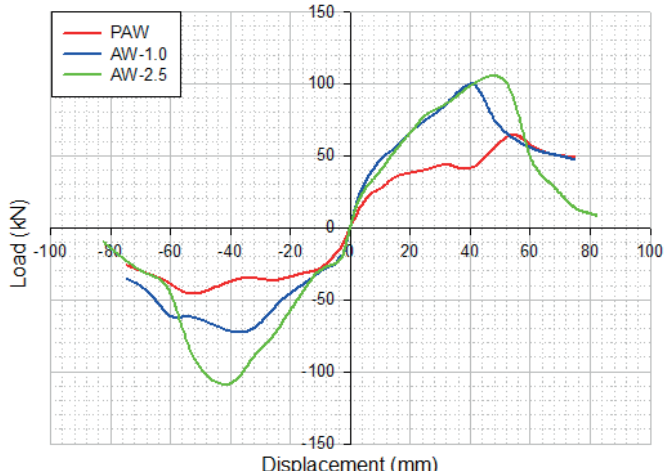

(c)

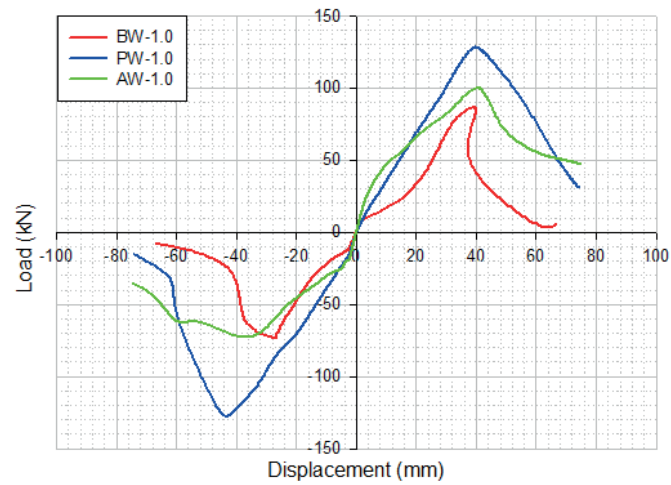

(e)

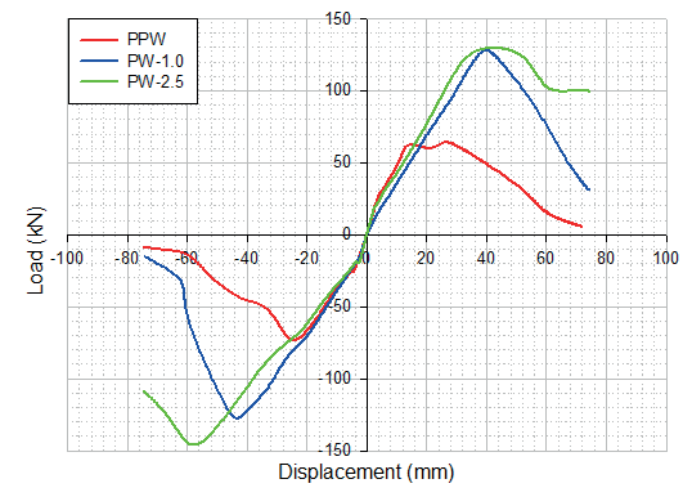

(b)

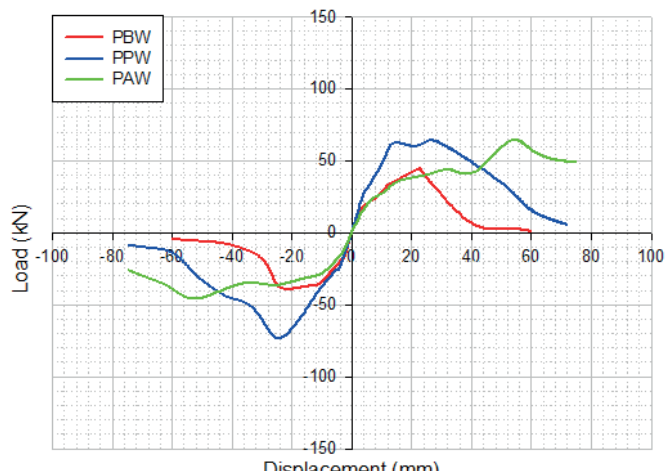

(d)

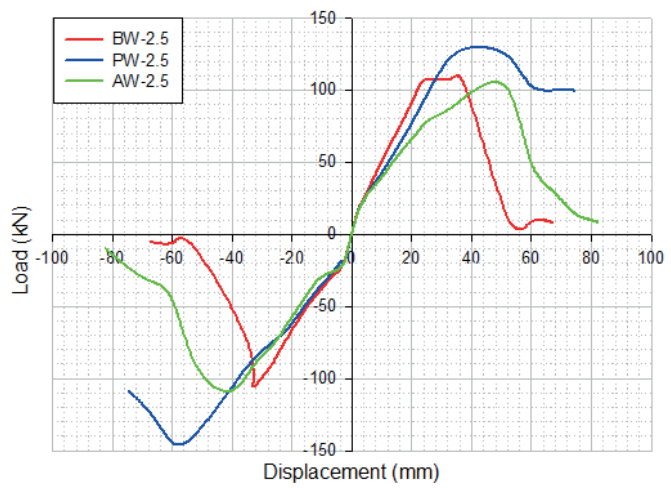

(f)

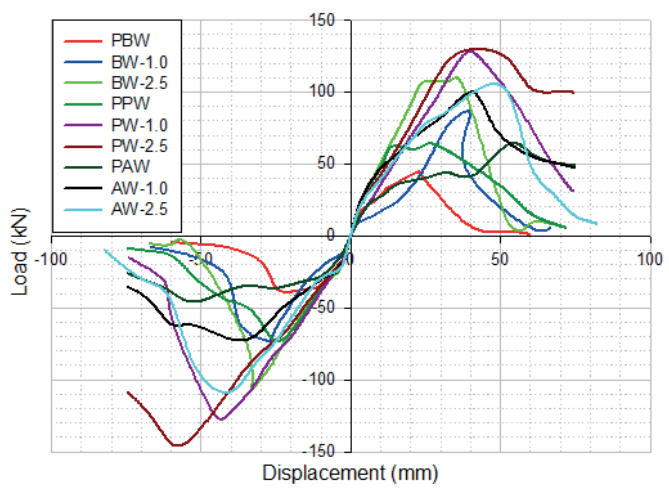

(g)

Fig. 5 Backbone curves of infill walls, (a) PBW,BW-1.0, BW-2.5 load-displacement curve; (b) PPW, PW-1.0, PW-2.5 load-displacement curve; (c) PAW, PAW-1.0, PAW-2.5 load-displacement curve; (d) PBW, PPW, PAW load-displacement curve; (e) BW-1.0, PW-1.0, AW-1.0 load-displacement curve; (f) BW-2.5, PW-2.5, AW2.5 load-displacement curve; (g) PBW, BW-1.0, BW2.5, PPW, PW-1.0, PW-2.5, PAW, AW-1.0, AW-2.5 load-displacement curve 
Table 4 Load capacity and stiffness in different steps of cyclic loading

\begin{tabular}{|c|c|c|c|c|c|c|c|c|}
\hline \multirow[t]{2}{*}{ Sample Name } & \multirow[t]{2}{*}{ Cycle Number } & \multicolumn{3}{|c|}{ Push } & \multirow[t]{2}{*}{ Cycle Number } & \multicolumn{3}{|c|}{ Pull } \\
\hline & & $\mathrm{P}$ & $\Delta$ & Stiffness & & $\mathrm{P}$ & $\Delta$ & Stiffness \\
\hline \multirow{7}{*}{ PBW } & & $(\mathrm{kN})$ & $(\mathrm{mm})$ & $(\mathrm{kN} / \mathrm{mm})$ & & $(\mathrm{kN})$ & $(\mathrm{mm})$ & $(\mathrm{kN} / \mathrm{mm})$ \\
\hline & 1 & 14.3 & 2.2 & 6.5 & 1 & 15.9 & 2.2 & 7.2 \\
\hline & 3 & 17.8 & 3.7 & 4.8 & 3 & 19.5 & 3.7 & 5.3 \\
\hline & 6 & 31.08 & 11.2 & 2.8 & 6 & 36.1 & 11.2 & 3.2 \\
\hline & 9 & 43.3 & 23.1 & 1.9 & 9 & 34.4 & 25.4 & 1.4 \\
\hline & 12 & 2.6 & 51.9 & 0.1 & 12 & 6.3 & 48.2 & 0.1 \\
\hline & 9 (Max) & 43.3 & 23.1 & 1.9 & 8 (Max) & 39.4 & 21 & 1.9 \\
\hline \multirow{6}{*}{ BW-1.0 } & 1 & 8.4 & 2.3 & 3.7 & 1 & 10.8 & 2.2 & 4.9 \\
\hline & 3 & 10.2 & 3.7 & 2.8 & 3 & 13.6 & 3.7 & 3.7 \\
\hline & 6 & 18.5 & 1.3 & 14.2 & 6 & 24.2 & 11.1 & 2.2 \\
\hline & 9 & 53.5 & 26.2 & 2.0 & 9 & 51.1 & 21 & 2.4 \\
\hline & 12 & 6.3 & 59.5 & 0.1 & 12 & 10.8 & 59.4 & 0.2 \\
\hline & 13 (Max) & 84.3 & 40.1 & 2.1 & 10 (Max) & 73 & 28 & 2.6 \\
\hline \multirow{6}{*}{ BW-2.5 } & 1 & 16.8 & 2.2 & 7.6 & 1 & 18 & 2.4 & 7.5 \\
\hline & 3 & 23.4 & 3.7 & 6.3 & 3 & 24 & 3.7 & 6.5 \\
\hline & 6 & 55.4 & 11.2 & 4.9 & 6 & 40.8 & 11.2 & 3.6 \\
\hline & 9 & 107.5 & 32.9 & 3.3 & 9 & 88.3 & 26.1 & 3.4 \\
\hline & 12 & 7.7 & 67 & 0.1 & 12 & 6 & 59.8 & 0.1 \\
\hline & 9 (Max) & 107.5 & 32.9 & 3.3 & 10 (Max) & 105.8 & 32.8 & 3.2 \\
\hline \multirow{6}{*}{ PPW } & 1 & 25.3 & 3.7 & 6.8 & 1 & 22.9 & 3.7 & 6.2 \\
\hline & 3 & 38.5 & 7.5 & 5.1 & 3 & 31.3 & 7.5 & 4.2 \\
\hline & 6 & 62.6 & 11.2 & 5.6 & 6 & 68.7 & 20.9 & 3.3 \\
\hline & 9 & 64.2 & 26.2 & 2.5 & 9 & 52.5 & 32.9 & 1.6 \\
\hline & 12 & 8.9 & 66.6 & 0.1 & 12 & 10.7 & 7.21 & 1.5 \\
\hline & 9 (Max) & 64.2 & 26.2 & 2.5 & 8 (Max) & 71.8 & 26.1 & 2.8 \\
\hline \multirow{6}{*}{ PW-1.0 } & 1 & 9.1 & 2.2 & 4.1 & 1 & 15.4 & 2.2 & 7.0 \\
\hline & 3 & 14.9 & 3.7 & 4.0 & 3 & 20.1 & 3.7 & 5.4 \\
\hline & 6 & 39.8 & 11.2 & 3.6 & 6 & 43.2 & 11.2 & 3.9 \\
\hline & 9 & 88.3 & 26.3 & 3.4 & 9 & 84.3 & 26.1 & 3.2 \\
\hline & 12 & 51.4 & 66.8 & 0.8 & 12 & 31.7 & 62.1 & 0.5 \\
\hline & 11 (Max) & 122.2 & 39.4 & 3.3 & 11 (Max) & 125 & 41.2 & 3.0 \\
\hline \multirow{6}{*}{ PW-2.5 } & 1 & 16.3 & 2.2 & 7.4 & 1 & 18.5 & 2.2 & 8.4 \\
\hline & 3 & 21.9 & 3.7 & 5.9 & 3 & 19.5 & 3.7 & 5.3 \\
\hline & 6 & 45.9 & 11.2 & 4.1 & 6 & 38 & 11.2 & 3.4 \\
\hline & 9 & 101 & 26 & 3.9 & 9 & 72 & 24.7 & 2.9 \\
\hline & 12 & 99.6 & 67.1 & 1.5 & 13 & 124.8 & 67.1 & 1.9 \\
\hline & 11 (Max) & 129.6 & 41 & 3.2 & 13 (Max) & 184.8 & 59.6 & 3.1 \\
\hline \multirow{6}{*}{ PAW } & 1 & 12.7 & 2.9 & 4.4 & 1 & 13.9 & 2.9 & 4.8 \\
\hline & 3 & 19.5 & 5.2 & 3.8 & 3 & 19 & 5.2 & 3.7 \\
\hline & 6 & 35.2 & 14.9 & 2.4 & 6 & 31.6 & 14.9 & 2.1 \\
\hline & 9 & 43.6 & 33 & 1.3 & 9 & 35.1 & 32.9 & 1.1 \\
\hline & 12 & 63.6 & 52.4 & 1.2 & 12 & 31 & 67.36 & 0.5 \\
\hline & 12 (Max) & 63.6 & 52.4 & 1.2 & 10 (Max) & 46.1 & 52.3 & 0.9 \\
\hline
\end{tabular}




\begin{tabular}{|c|c|c|c|c|c|c|c|c|}
\hline \multirow[t]{2}{*}{ Sample Name } & \multirow[t]{2}{*}{ Cycle Number } & \multicolumn{3}{|c|}{ Push } & \multirow[t]{2}{*}{ Cycle Number } & \multicolumn{3}{|c|}{ Pull } \\
\hline & & $\mathrm{P}$ & $\Delta$ & Stiffness & & $\mathrm{P}$ & $\Delta$ & Stiffnes \\
\hline \multirow{6}{*}{ AW-1.0 } & 1 & 17 & 2.2 & 7.7 & 1 & 18.4 & 2.2 & 8.4 \\
\hline & 3 & 25.9 & 3.7 & 7.0 & 3 & 22.7 & 3.7 & 6.1 \\
\hline & 6 & 49.6 & 11.2 & 4.4 & 6 & 32.4 & 11.2 & 2.9 \\
\hline & 9 & 76.5 & 26.2 & 2.9 & 9 & 57.6 & 26.2 & 2.2 \\
\hline & 12 & 50.75 & 67.4 & 0.8 & 12 & 44.5 & 67.4 & 0.7 \\
\hline & 11 (Max) & 99.7 & 41.2 & 2.4 & 11 (Max) & 71.9 & 39.9 & 1.8 \\
\hline \multirow{6}{*}{ AW-2.5 } & 1 & 15.6 & 2.2 & 7.1 & 1 & 18.2 & 2.2 & 8.3 \\
\hline & 3 & 2.2 & 3.7 & 0.6 & 3 & 23.3 & 3.7 & 6.3 \\
\hline & 6 & 42.5 & 11.2 & 3.8 & 6 & 31.6 & 11.2 & 2.8 \\
\hline & 9 & 80 & 26.2 & 3.0 & 9 & 76.4 & 26.2 & 2.9 \\
\hline & 12 & 13.8 & 74.8 & 0.18 & 12 & 22.6 & 74.9 & 0.3 \\
\hline & 11 (Max) & 100.4 & 41.2 & 2.43 & 11 (Max) & 109.1 & 41.1 & 2.65 \\
\hline
\end{tabular}

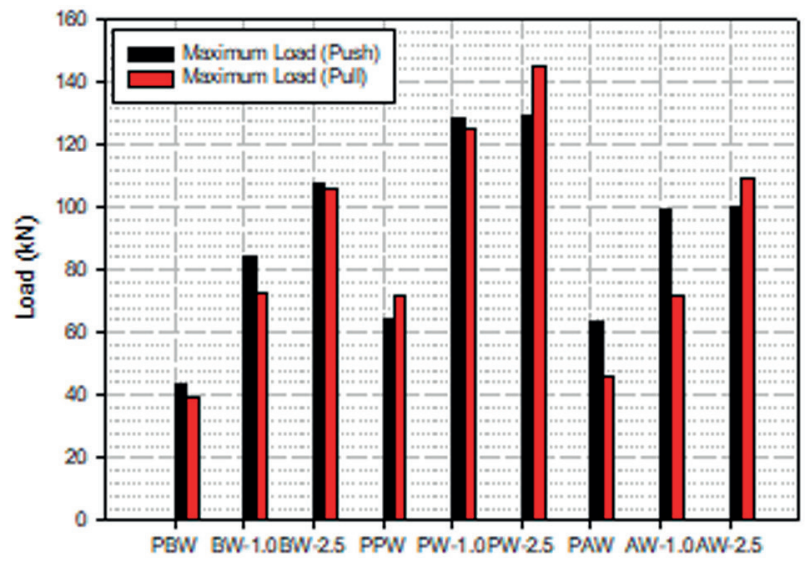

Fig. 6 Load carrying capacities of infill walls

PAW walls. Under pull force of the cyclic loading, the application of $1 \mathrm{~cm}$ plaster to all the tested infill walls increased the stiffness by $36.8 \%$ in PBW, $7.1 \%$ in PPW and $100 \%$ in PAW walls. It means that by increasing of the plaster thickness, stiffness of the infill walls increased in all three types.

Under pull force of the cyclic loading, the application of $2.5 \mathrm{~cm}$ plaster to all the tested infill walls increased the stiffness by $73.6 \%$ in PBW, $28 \%$ in PPW and $102 \%$ in PAW walls. Under pull force of the cyclic loading, the application of $2.5 \mathrm{~cm}$ plaster to all the tested infill walls increased the stiffness by $68 \%$ in PBW, $10.7 \%$ in PPW and $194 \%$ in PAW walls. It means that by increasing the plaster thickness, stiffness of the infill walls increased in all three types.

\subsection{Energy dissipation capacities}

The total dissipated energies of the test walls were obtained by collecting cumulatively the areas under the load-displacement curve for each cycle. Using the obtained data from the infill walls, the relationship between the total dissipated energy and corresponding drift ratios were determined. Cumulative dissipated energy-drift ratio curves of the test walls are given in Fig. 7 to Fig. 10. Also, the cumulative dissipated energies for each wall were illustrated in Fig. 11 as bar diagram for better understanding.

When the energy dissipation capacities of the infill walls were examined, it was seen that the infill wall materials affects and the plaster thickness applied to the walls made significant contribution to the energy dissipation capacity of the infill walls.

Under cyclic loading, the application of $1 \mathrm{~cm}$ plaster to all the tested infill walls increased the energy capacities by $41 \%$ in PBW, $2.7 \%$ in PPW and $100.5 \%$ in PW walls. In addition, the application of $2.5 \mathrm{~cm}$ plaster to all the tested infill walls increased the energy capacities by $172 \%$ in PBW, $55 \%$ in PW and $90 \%$ in PPW. We concluded that by increasing the plaster thickness, energy capacities of the infill walls increased in all three types.

When energy dissipation curves of horizontal hollow bricks infill walls were examined, energy dissipation capacities are similar at $2.0 \%$ drift ratio (Fig. 7). As this value exceeded, damages of the PBW wall that were produced without plaster under increasing displacements, became visible. This result showed that plasters have an impact on the total energy consumed, as well as load carrying capacity.

When the energy dissipation capacities of the pumice block infill walls were compared with each other similarly at $2.0 \%$ drift ratio level all the walls have close energy dissipation capacities (Fig. 8). After this value effect of damages can be clearly seen on non-plastered wall coded as PPW. Besides PW-1.0 and PW-2.5 showed almost the 


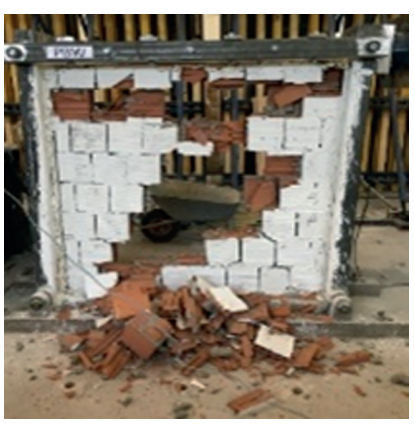

(a) PBW

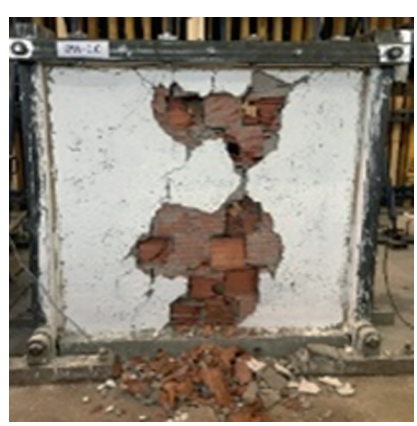

(b) BW1.0

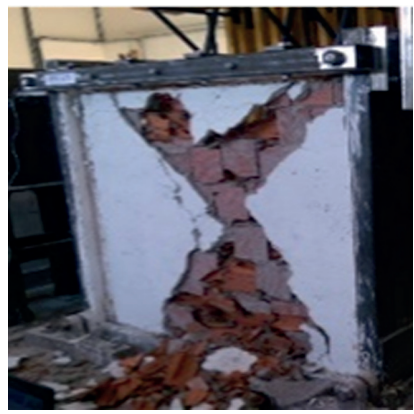

(c) BW2.5

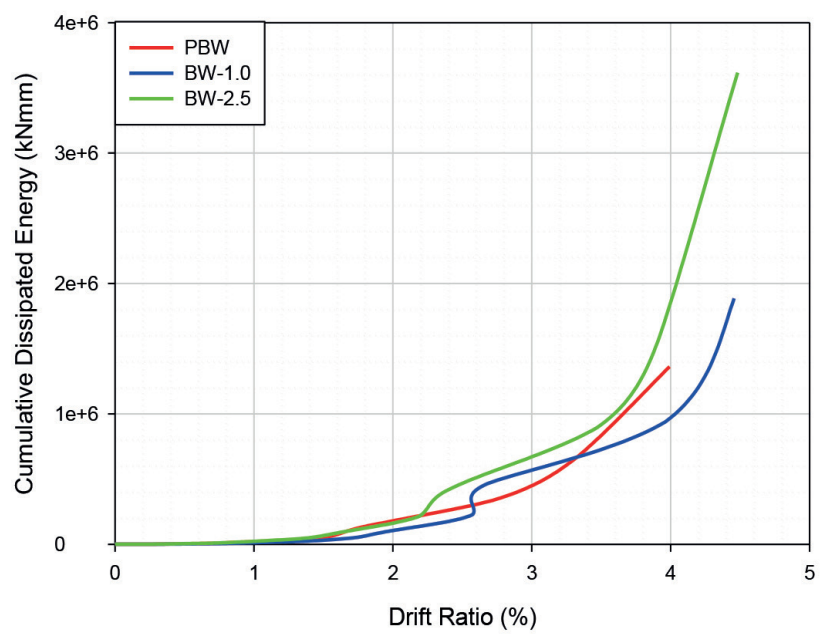

Fig. 7 Cumulative dissipated energies of horizontal hollow brick walls

same behavior. As load carrying capacity of PW-2.5 is higher and damages are limited, its total dissipated energy is higher than that of PW-1.0. However, it is seen that energy dissipation on the non-plastered PPW wall was slightly higher. This shows that the effect of plaster is the least for pumice walls.

When the energy dissipation capacities of aerated concrete infill walls are examined, the effect of the presence of plaster is more evident. However, the dissipated energies of AW-1.0 and AW-2.5 test walls were almost overlapped. This result shows that the effect of the plaster thickness is quite low after a certain displacement value for aerated concrete block infill walls (Fig. 9).

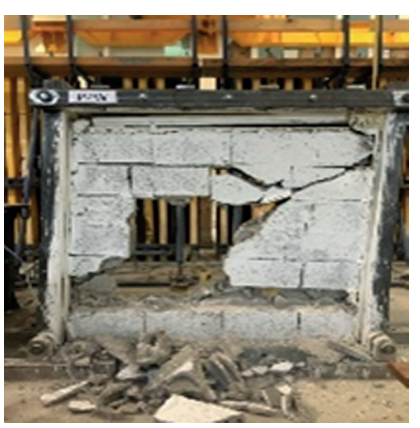

(a) PPW

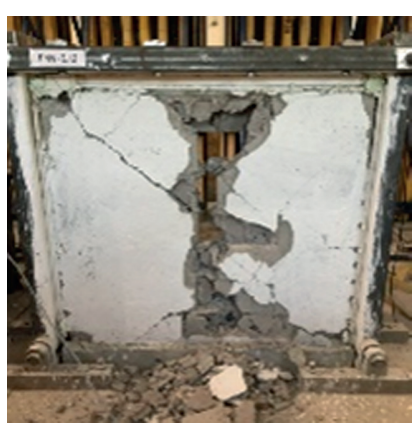

(b) PPW-1.0

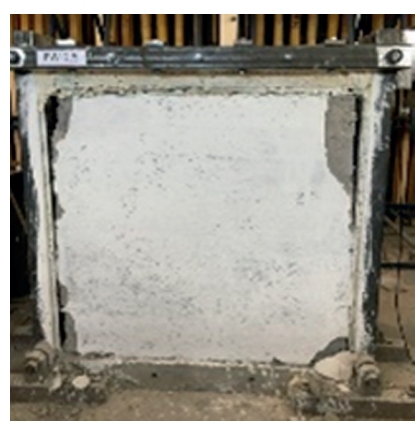

(c) PPW-2.5

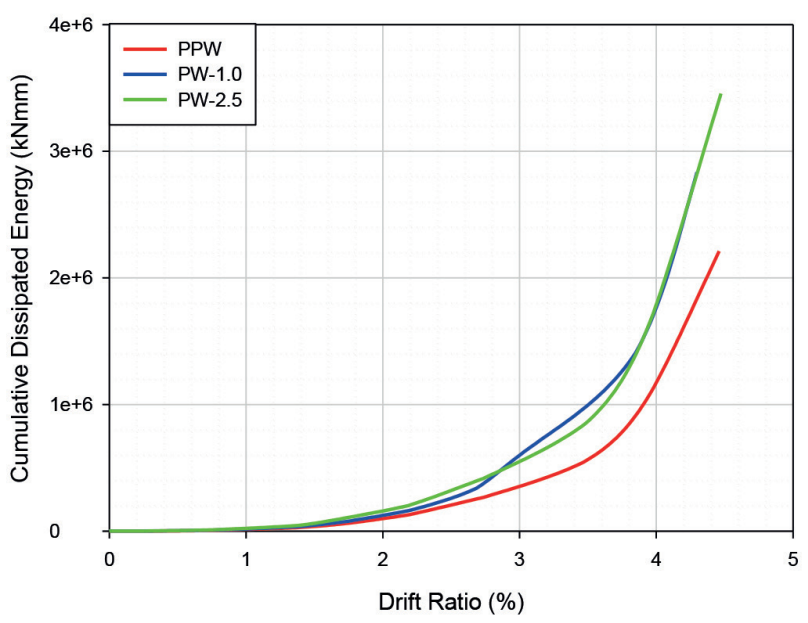

Fig. 8 Cumulative dissipated energies of pumice block walls

When the non-plastered and plastered walls are examined among themselves, the PPW wall has the highest energy dissipation capacity. This situation shows that the pumice block walls in plain form show more ductile behavior. In addition, it should be noted here that the cumulative energy dissipation capacity of the aerated concrete infill wall is also quite high (Fig. 10). When three different walls with a plaster thickness of $1.0 \mathrm{~cm}$ are examined, it is observed that AW-1.0 is very ductile. Besides, the increase in energy dissipation for the pumice and aerated concrete infill walls almost overlap with each other. The lowest energy dissipation value was obtained for the BW-1.0 wall (Fig. 10). When the energy dissipation of the infill walls 


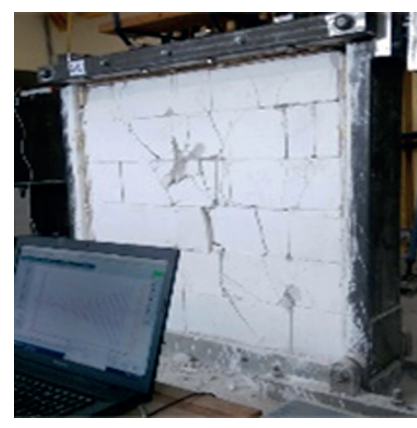

(a) AW

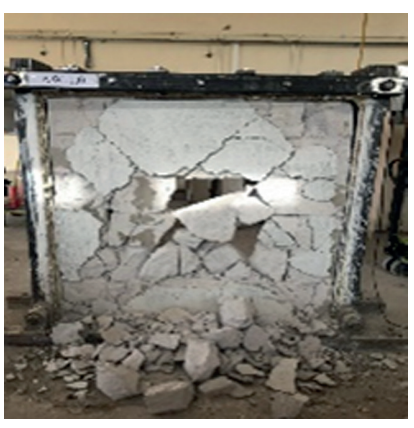

(b) PAW-1.0

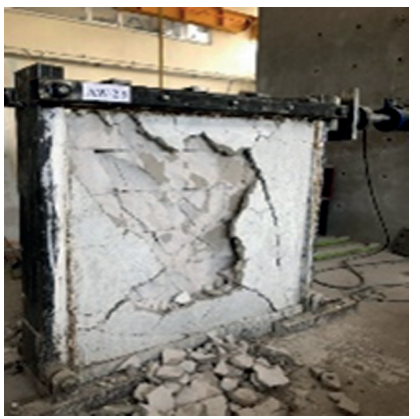

(c) AW-2.5

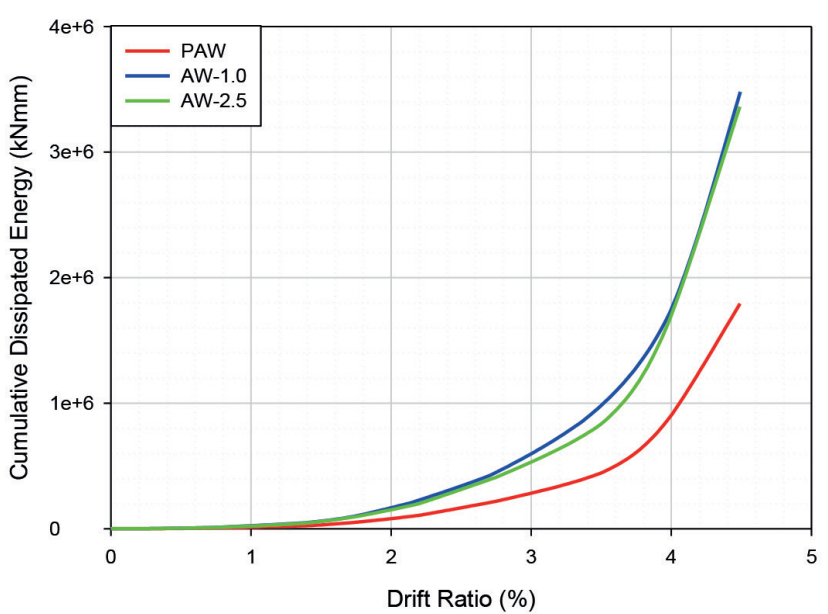

Fig. 9 Cumulative dissipated energies of aerated concrete block walls

with a thickness of $2.5 \mathrm{~cm}$ is examined, it is seen that all the walls dissipate almost the same amount of energy. This shows that the thickness of the plaster increases the energy dissipation capacity of the brick infill walls considerably (Fig. 11).

\section{Conclusions}

In this study, the effects of the materials used in the producing of infill walls and the applied plaster thicknesses on the behavior of the walls under the lateral cyclic loading were investigated comparatively. For this purpose, three Infill walls that were produced from three different materials

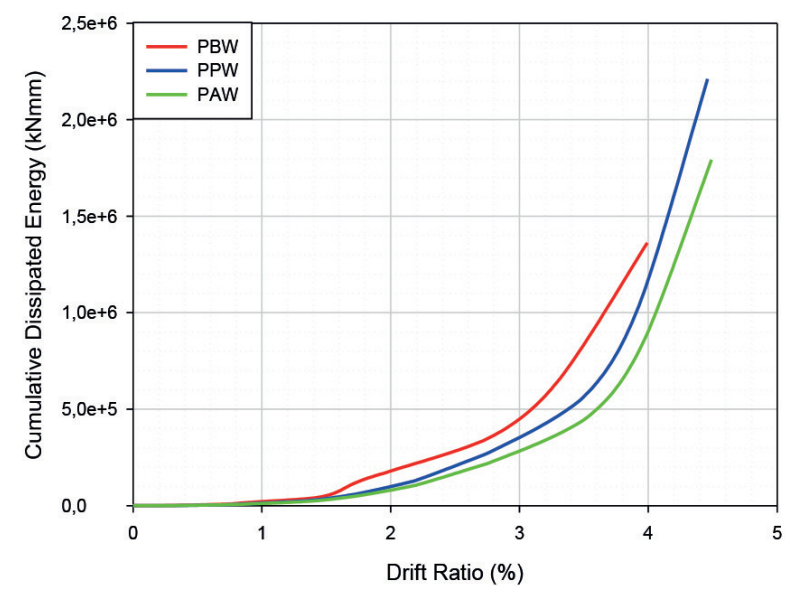

(a)

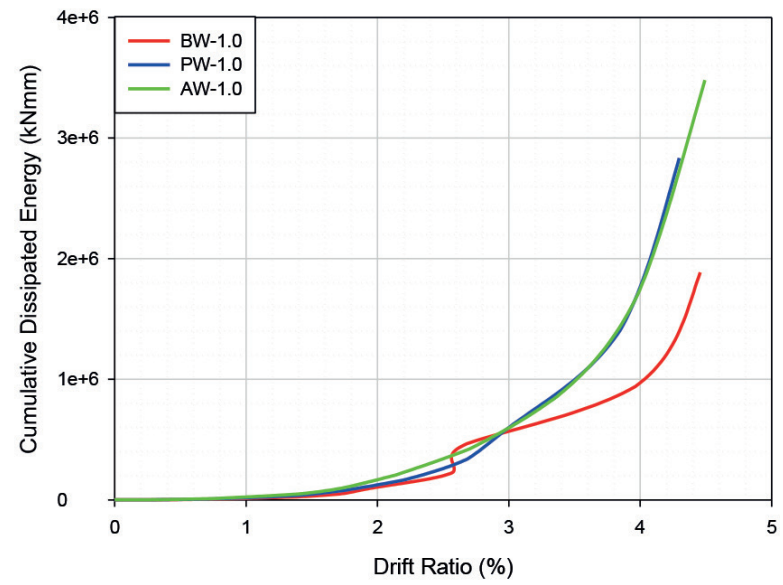

(b)

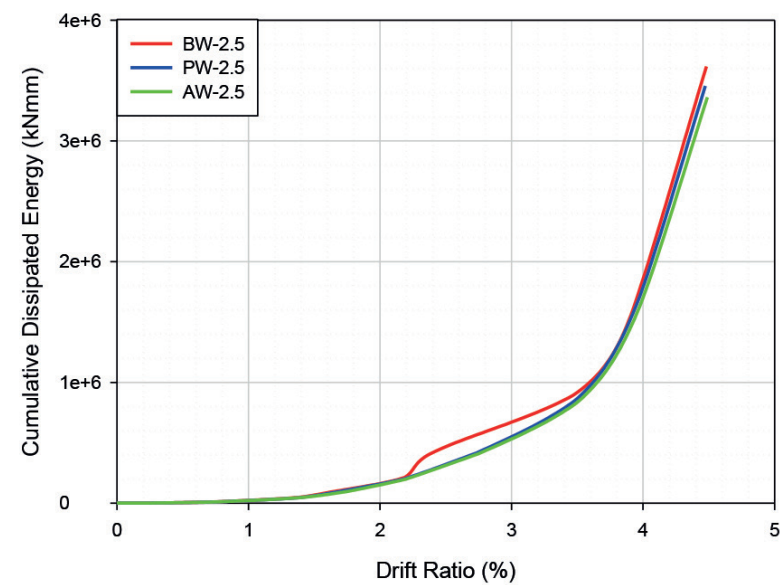

(c)

Fig. 10 Cumulative dissipated energy graph of horizontal hollowed bricks, pumice and aerated concrete blocks, (a) without plaster; (b) applied with $1 \mathrm{~cm}$ of plaster; (c) applied with $2.5 \mathrm{~cm}$ of plaster

namely, horizontal hollow bricks, pumice blocks and aerated concrete blocks were tested in three setups (without plaster, with $1 \mathrm{~cm}$ plaster and $2.5 \mathrm{~cm}$ plaster on it). In order to conduct the test, infill walls with $150 \mathrm{~cm} \times 150 \mathrm{~cm}$ dimensions were constructed using horizontal hollow brick, as 


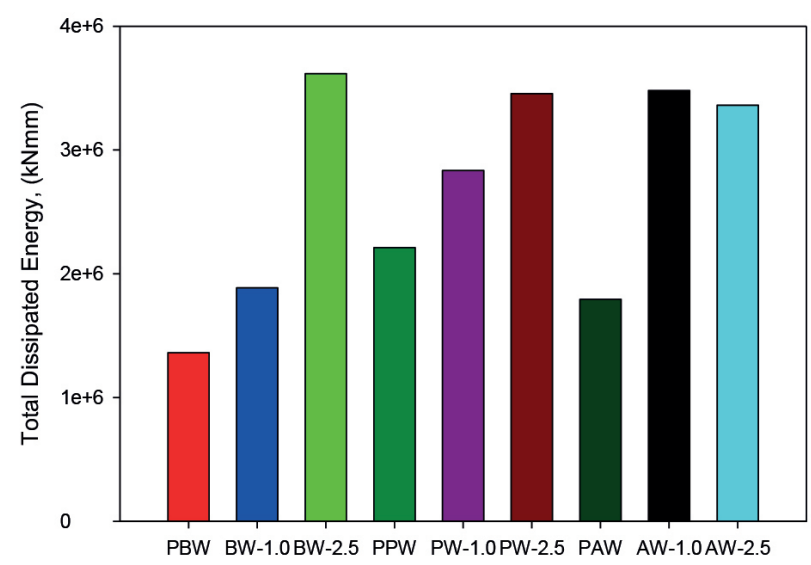

Fig. 11 Total dissipated energies of the infill walls

well as pumice and aerated concrete blocks. Thickness of the mortar joints were approximately $10 \mathrm{~mm}$ for brick and Bims block. For aerated concrete blocks, a special mortar with a thin layer was used. The above-mentioned walls were subjected to horizontal cyclic loading using a test setup hinged from four corners. The data obtained from this study points toward the following conclusions:

- PW-2.5 test wall has the highest load carrying capacity under cyclic loading. Also, a considerable increase in load carrying capacities of all the test walls is observed proportional to the plaster thickness.

- Under lateral cyclic loading, the application of $1 \mathrm{~cm}$ plaster to all the tested infill walls increased the load carrying capacity from 85.2-95 \% in PBW, 74-92 \% in PPW and $55 \%$ in PAW walls, respectively, both in push and pull directions. It means that by increasing the plaster thickness, load carrying capacities of the infill walls have increased in all three types.

- Under lateral cyclic loading, the application of $2.5 \mathrm{~cm}$ plaster to all the tested infill walls increased the load carrying capacity from $148-169 \%$ in PBW, $101-157 \%$ in PPW and $58-136 \%$ in PAW walls

\section{References}

[1] Arslan, M. E., Erkan, C. "An experimental study on cyclic behavior of aerated concrete block masonry walls retrofitted with different methods", Construction and Building Materials, 200, pp. 226-239, 2019. https://doi.org/10.1016/j.conbuildmat.2018.12.132

[2] Altin, S., Anil, Ö., Kara, M. E., Kaya, M. "An experimental study on strengthening of masonry infilled RC frames using diagonal CFRP strips", Composites Part B: Engineering, 39(4), pp. 680-693, 2008. https://doi.org/10.1016/j.compositesb.2007.06.001

[3] Govindan, P., Lakshmipathy, M., Santhakumar, A. R. "Ductility of Infilled Frames", Journal Proceedings, 83(4), pp. 567-576, 1986.

[4] Smith, B. S. "Lateral stiffness of infilled frames", Journal of the Structural Division, 88(6), pp. 183-226, 1962. respectively, in push and pull directions. It means that by increasing the plaster thickness, load carrying capacities of the infill walls have increased in all specimens. PW-2.5 test wall had the highest load carrying capacity under cyclic loading.

- The increase in stiffness was calculated as $10.5 \%$ for PBW, $32 \%$ for PPW and $100 \%$ for PAW by adding $1 \mathrm{~cm}$ plaster to both sides of the walls. In addition, the increase in stiffness was distinctly observed by adding $2.5 \mathrm{~cm}$ plaster for all specimens and the result was $73.6 \%$ increase in PBW, $28 \%$ in PPW and $102 \%$ in PAW walls respectively, in push and pull directions. We concluded that by increasing the plaster thickness, stiffness of the infill walls has increased in all three types.

- Energy dissipation capacity of the infill walls has increases by adding the plaster to both sides of the walls. By adding $1 \mathrm{~cm}$, plaster to all the tested infill walls the energy capacities has increased by $41 \%$ in PBW, $2.7 \%$ in PPW and $100.5 \%$ in PW walls. In addition, the application of $2.5 \mathrm{~cm}$ plaster to all the tested infill walls increased the energy capacities by $172 \%$ in PBW, $55 \%$ in PW and $90 \%$ in PPW. It means that by increasing the plaster thickness, the energy capacities of the infill walls have increased in all three types.

As a result of the experimental data obtained in the horizontal cyclic charge effect, it can be said that infill walls produced with the pumice blocks have higher strength than those infill walls that were produced with brick and aerated concrete blocks. Even though total dissipated energies are similar for $2.5 \mathrm{~cm}$ thickness infill walls, BW-2.5 has the highest total dissipated energy. To conclude, there has been an overall increment in the parameters such as load carrying capacity, energy dissipation capacity, and stiffness of the wall elements after applying plaster to the infill walls.

[5] Calvi, G. M., Kingsley, G. R., Magenes, G. "Testing of Masonry Structures for Seismic Assessment", Earthquake Spectra, 12(1), pp. 145-162, 1996. https://doi.org/10.1193/1.1585872

[6] Negro, P., Verzeletti, G. "Effect of infills on the global behaviour of R/C frames: energy considerations from pseudo dynamic tests", Earthquake Engineering and Structural Dynamics, 25(8), pp. 753773, 1996.

https://doi.org/10.1002/(SICI)1096-9845(199608)25:8<753::AIDEQE578>3.0.CO;2-Q

[7] Dowrick, D. J. "Earthquake Resistant Design for Engineers and Architects", Wiley, Lower Hutt, New Zealand 1987. 
[8] Arslan, M. E. "Experimental and theoretical investigation of behaviour of in-filled RC frames strengthened with GFRP under cyclic loading", PhD Dissertation, Karadeniz Technical University, 2013.

[9] Brodsky, A., Rabinovitch, O., Yankelevsky, D. Z. "Effect of masonry joints on the behavior of infilled frames", Construction and Building Materials, 189, pp. 144-156, 1996.

https://doi.org/10.1016/j.conbuildmat.2018.08.209

[10] Facconi, L., Minelli, F., Giuriani, E. "Response of infilled RC frames retrofitted with a cementitious fiber-mesh reinforced coating in moderate seismicity areas", Construction and Building Materials, 160, pp. 574-587, 2018.

https://doi.org/10.1016/j.conbuildmat.2017.11.033

[11] Ismail, N., El-Maaddawy, T., Khattak, N. "Quasi-static in-plane testing of FRCM strengthened non-ductile reinforced concrete frames with masonry infills", Construction and Building Materials, 186, pp. 1286-1298, 2018.

https://doi.org/10.1016/j.conbuildmat.2018.07.230

[12] Altin, S., Ersoy, U., Tamkut, T. "Hysteretic Response of ReinforcedConcrete Infilled Frames", Journal of Structural Engineering, 118(8), pp. 2133-2150, 1992.

https://doi.org/10.1061/(ASCE)0733-9445(1992)118:8(2133)

[13] Arslan, M. E., Durmuş, A., Hüsem, M. "Cyclic behavior of GFRP strengthened infilled RC frames with low and normal strength concrete", Science and Engineering of Composite Materials, 26(1), pp. 30-42, 2019.

https://doi.org/10.1515/secm-2017-0060

[14] Knox, C. L., Dizhur, D., Ingham, J. M. "Two-Story Perforated URM Wall Subjected to Cyclic In-Plane Loading", Journal of Structural Engineering, 144(5), 2018.

https://doi.org/10.1061/(ASCE)ST.1943-541X.0002021

[15] Anil, Ö., Altin, S. "An experimental study on reinforced concrete partially infilled frames", Engineering Structures, 29(3), pp. 449460, 2007.

https://doi.org/10.1016/j.engstruct.2006.05.011

[16] Haris, I., Hortobágyi, Z. "Comparison of Experimental and Analytical Results on Masonry Infilled RC Frames for Cyclic Lateral Load", Periodica Polytechnica Civil Engineering, 59(2), pp. 193-208, 2015. https://doi.org/10.3311/PPci.8099

[17] Haris, I., Hortobágyi, Z. "Comparison of experimental and analytical results on masonry infilled RC frames for monotonic increasing lateral load", Periodica Polytechnica Civil Engineering, 56(2), pp. 185-196, 2012.

https://doi.org/10.3311/pp.ci.2012-2.05

[18] Arslan, M. E., Emiroğlu, M., Yalama, A. "Structural behavior of rammed earth walls under lateral cyclic loading: A comparative experimental study", Construction and Building Materials, 133, pp. 433-442, 2017. https://doi.org/10.1016/j.conbuildmat.2016.12.093

[19] Candeias, P. X., Campos Costa, A., Mendes, N., Costa, A. A., Lourenço, P. B. "Experimental Assessment of the Out-of-Plane Performance of Masonry Buildings Through Shaking Table Tests", International Journal of Architectural Heritage, 11(1), pp. 31-58, 2017. https://doi.org/10.1080/15583058.2016.1238975
[20] Reboul, N., Mesticou, Z., Si Larbi, A., Ferrier, E. "Experimental study of the in-plane cyclic behaviour of masonry walls strengthened by composite materials", Construction and Building Materials, 164, pp. 70-83, 2018. https://doi.org/10.1016/j.conbuildmat.2017.12.215

[21] Farooq, S. H., Ilyas, M., Amir, S. "Response of Masonry Walls Strengthened with CFRP and Steel Strips", Arabian Journal for Science and Engineering, 37, pp. 545-559, 2012. https://doi.org/10.1007/s13369-012-0190-9

[22] Zhang, S., Yang, D., Sheng, Y., Garrity, S. W., Xu, L. "Numerical modelling of FRP-reinforced masonry walls under in-plane seismic loading", Construction and Building Materials, 134, pp. 649-663, 2017.

https://doi.org/10.1016/j.conbuildmat.2016.12.091

[23] Mustafaraj, E., Yardim, Y. "In-plane Shear Strengthening of Unreinforced Masonry Walls Using GFRP Jacketing", Periodica Polytechnica Civil Engineering, 62(2), pp. 330-336, 2018. https://doi.org/10.3311/PPci.11311

[24] Sathiparan, N. "Effect of Roof and Diaphragm Connectivity on Dynamic Behaviour of the PP-band Retrofitted Adobe Masonry Structures", Periodica Polytechnica Civil Engineering, 62(4), pp. 992-1000, 2018.

https://doi.org/10.3311/PPci.12247

[25] Farooq, S. H., Ilyas, M., Ghaffar, A. "Technique for strengthening of masonry wall panels using steel strips", Asian Journal of Civil Engineering, 7(6), pp. 621-638, 2006.

[26] Haris, I., Farkas, G. "Experimental Results on Masonry Infilled RC Frames for Monotonic Increasing and Cyclic Lateral Load", Periodica Polytechnica Civil Engineering, 62(3), pp. 772-782, 2018. https://doi.org/10.3311/PPci.10715

[27] Karaton, M., Aksoy, H. S. "Seismic Damage Assessment of an 891 Years Old Historic Masonry Mosque", Periodica Polytechnica Civil Engineering, 62(1), pp. 126-135, 2018.

https://doi.org/10.3311/PPci.10270

[28] Srisanthi, V. G., Keshav, L., Kumar, P. P., Jayakumar, T. "Finite Element and Experimental Analysis of 3d Masonry Compressed Stabilised Earth Block and Brick Building Models against Earthquake Forces", Periodica Polytechnica Civil Engineering, 58(3), pp. 255-265, 2014. https://doi.org/10.3311/PPci.7443

[29] Hokelekli, E., Yilmaz, B. N. "Effect of Cohesive Contact of Backfill with Arch and Spandrel Walls of a Historical Masonry Arch Bridge on Seismic Response", Periodica Polytechnica Civil Engineering, 63(3), pp. 926-937, 2019. https://doi.org/10.3311/PPci.14198

[30] Senturk, M. "The effects of different plaster thicknesses on the behavior of infill walls under horizontal", Master Thesis, Sakarya University, 2018. 